\title{
POVOAMENTOS E RESISTÊNCIAS ENTRE DOCÊNCIA E CRIAÇÃO NO ENSINO DAS ARTES
}

\begin{abstract}
RESUMO: O artigo surge como parte dos resultados, do aporte teórico e das ações desenvolvidas pela pesquisa intitulada Docência e criação em educação das artes visuais: povoamentos entre visualidades, leituras e escritas, coordenada pelo autor. Apresenta, assim, um arranjo elaborado com as noções presentes em seu título especialmente criação, resistência/re-existência, povoamento e arte - para convidar o leitor a pensar concepções que envolvam uma possível perspectiva de formação de docências, a fim de atuar na educação das artes na contemporaneidade. Desse modo, o texto apresenta um modo de se relacionar com conceitos e imagens, tanto no que tange à própria investigação, quanto ao que se refere àquilo que acaba respingando no ambiente formativo de professores de artes visuais. No fim, apresenta e discute brevemente a proposta artístico-educacional Postais para o Futuro, idealizada e conduzida também pelo autor, como modo de evidenciar formas de ler e escrever com imagens em um horizonte que concebe palavras e visualidades como dispositivos de invenção, para além de anteparos de significação.
\end{abstract}

Palavras-chave: Criação, Formação, Docência, Educação, Arte.

\section{SETTLEMENTS AND RESISTANCE BETWEEN TEACHING AND CREATION IN ART EDUCATION}

\begin{abstract}
The article emerges as part of the results, the theoretical basis and the actions developed by the research entitled Teaching and creation in visual arts education: stands between visuals, reading and writing, coordinated by the author. It presents, therefore, an elaborate arrangement with the notions present in its title - especially creation, resistance/re-existence, settlement and art - to invite the reader to think about concepts that involve a possible perspective for teacher training in the work with art education in contemporaneity. In this way, the text presents a way of relating to concepts and images, both with regard to research itself, as with what ends up contaminating in the formative environment of teachers of visual arts. In the end, it briefly presents and discusses the artistic-educational proposal Postcards for the Future, also idealized and carried out by the author, as a way of evidencing forms of reading and writing with images in a horizon that conceives words and visualities as invention devices, beyond signifying frameworks.
\end{abstract}

Keywords: Creation, Training, Teaching, Education, Art.

\section{ASENTAMIENTOS Y RESISTENCIAS ENTRE DOCENCIA Y CREACIÓN EN ENSEÑANZA DE LAS ARTES}

\footnotetext{
${ }^{1}$ Universidade Federal do Rio Grande do Sul (UFRGS). Porto Alegre, RS, Brasil. < cristianmossi@gmail.com>
} Educação em Revista|Belo Horizonte|v.36|e219274|2020 
RESÚMEN: El artículo aparece como parte de los resultados, la contribución teórica y las acciones desarrolladas por la investigación titulada Enseñanza y creación en la educación de las artes visuales: asentamientos entre visualidades, lecturas y escritos, coordinados por el autor. Por lo tanto, presenta una disposición elaborada con las nociones presentes en su título, especialmente creación, resistencia / reexistencia, asentamiento y arte, para invitar al lector a pensar en concepciones que involucran una posible perspectiva de la formación docente, para actuar en educación artística contemporánea. De esta manera, el texto presenta una forma de relacionarse con conceptos e imágenes, tanto con respecto a la investigación en sí misma, como con respecto a lo que termina salpicando en el ambiente formativo de los maestros de artes visuales. Al final, presenta y discute brevemente la propuesta artístico-educativa Postales para el futuro, idealizada y también dirigida por el autor, como una forma de mostrar formas de leer y escribir con imágenes en un horizonte que concibe palabras y visualidades como dispositivos de invención, más allá de escudos de importancia.

Palabras clave: Creación, Formación, Docencia, Educación, Arte.

\section{INTRODUÇÃO}

O texto que se segue é resultante especialmente do aporte teórico, de algumas ações e dos resultados iniciais da pesquisa intitulada Docência e criação em educação das artes visuais: povoamentos entre visualidades, leituras e escritas ${ }^{2}$, coordenada por mim junto à minha instituição de origem, que apresentarei com maior detalhamento mais adiante. Em outras palavras, a presente escrita contempla o modo como tenho me relacionado com alguns conceitos, noções e imagens, tanto no que tange à própria investigação, como com o que acaba inevitavelmente respingando em sala de aula, no ambiente formativo de professores de artes visuais e em algumas iniciativas que permeiam esses espaços.

Destarte, cabe afirmar que, tanto na investigação em questão como neste artigo, as noções de 'povoamento' e de 'resistência/re-existência' estão imbricadas ao conceito de criação. As noções mais amplas de docência e de arte e, mais especificamente, de formação docente para o ensino das artes, são pensadas como alguns dos dominios específicos (DELEUZE, 1999) em que a criação/invenção (e, por sua vez, os povoamentos e as resistências/re-existências) a que me refiro aqui podem ser ensaiados/experienciados.

Nesse sentido, a problemática que orienta a presente escrita vem indagar que povoamentos e resistências/re-existências são possíveis ao aproximarmos a noção de criação ao ensino e à formação docente das/em artes. Para tanto, no que concerne à sua perspectiva teórica, o artigo se sustenta especialmente em Deleuze (1999), Kastrup (2001, 2009, 2016), Corazza (2013) e Loponte (2003, 2013) para colocar em operação as já mencionadas noções de criação/invenção, povoamento e resistência/reexistência, articulando-as às noções de docência e de arte, ou de ensino e formação docente das/em artes. No que tange à sua perspectiva metodológica, o texto busca encadeamentos - ou nós, pontos de conexão -, como uma linha invisível que atravessa e sugere um arranjo compositivo entre tais conceitos mencionados, de modo a mapear concepções que envolvam uma possível perspectiva de formação e de ensino das artes na contemporaneidade, nos seus mais diversos níveis, modalidades e contextos.

Não se trata de uma listagem de prescrições, mas de escritos (e, em alguns momentos, de imagens) que visam expor (de forma ensaística, poderíamos dizer) algumas das intuições implicadas nesse ponto de vista formativo/educacional em que tenho lecionado e pesquisado, inspirado pelos autores já citados. Busca-se convidar o leitor ao pensamento, a outras composições/proposições e a outros arranjos que podem ser produzidos a partir daqui.

Pontuarei, em linhas gerais, o objeto do qual tem se ocupado a pesquisa mencionada, aliando à breve exposição desses intuitos investigativos a necessidade de que outros/novos argumentos sejam

\footnotetext{
2 Pesquisa desenvolvida junto à Faculdade de Educação (Faced) da Universidade Federal do Rio Grande do Sul (UFRGS), no período compreendido entre os anos de 2016 e 2019. Conta com uma bolsa de iniciação científica financiada pela própria universidade (Bolsista IC Carolina Goulart Kneipp). 
cunhados para o ensino das artes na contemporaneidade. Em seguida, apresentarei algumas concepções acerca do modo como tenho compreendido as urgências desse ensino para, posteriormente, expor um arranjo composto pelas noções de criação, resistência/re-existência, povoamento e arte. Tal arranjo de modo algum servirá para enclausurar compreensões e conceitos em definições restritivas, mas para operálos, colocá-los em funcionamento na produção de uma territorialidade provisória que ensaia certa perspectiva de formação e de ensino/educação sempre em artesania. Finalmente, concluirei o texto contando um pouco sobre uma das ações que compõem a pesquisa aqui em questão.

\section{"Porque nem só o verbo dá conta do diálogo e do afeto": criar outros modos de ser docente e outros argumentos para o ensino das artes.}

Porque se acorda e se toma café.

Se sai para a rua, se vê o outdoor.

Se vai até a escola e se senta na cadeira.

Se ouve e vê e transcreve.

Se sai da escola e pega ônibus e se segura para não cair, se dá lugar para o outro sentar, se segura a sacola de alguém.

Se chega em casa, senta para fazer tarefa.

Se liga a TV. Se desliga a TV.

Se diz boa noite, se vai dormir.

Porque nem só o verbo dá conta do diálogo e do afeto.

Porque só a tela não ensina a entender imagem.

A Educação Física e o caminhar não resolvem a necessidade de fazer do corpo.

Ceder o lugar não é o unico jeito de ver o bumano, tampouco o é somente a História ou as Ciências Sociais, nem a Geografia, que não é tudo o que bá no caminho da Escola, assim como a Física.

Nem a transcrição do que se ouve ou a feitura da tarefa são o conbecimento. Nem escutar, ver e entender se resolvem pela palavra.

Nem a Filosofia sozinha motiva o dormir e acordar.

Enquanto professor formador de um curso de Licenciatura em Artes Visuais, ministrando as disciplinas de Estágio Curricular Supervisionado em Artes Visuais, tenho me ocupado, tanto em minhas atividades de ensino, como em minhas investigações - ambientes esses, a meu ver, indissociáveis -, em mapear as inter-relações que podem ser possíveis ao entrecruzarmos o conceito de criação (pensado especialmente sob a perspectiva pontuada por Gilles Deleuze em sua conferência "O ato de criação", de 1987, publicada no Brasil pela Folha de São Paulo no ano de 1999) com as trajetórias singulares produzidas e percorridas nas formações docentes, sobretudo no campo do ensino das artes. ${ }^{4}$

De modo a cumprir tal objetivo na já mencionada pesquisa, tenho olhado para escritas/leituras e imagens produzidas e/ou apropriadas por professores em seus percursos iniciais de formação, em vista do modo como, de forma singular, cada um "acolhe e honra os elementos científicos, filosóficos e artísticos - extraídos de obras já realizadas, que diversos autores criaram, em outros planos, tempos, espaços" e, a partir desses elementos, "constitui um campo artistador de variações múltiplas e disjunções inclusivas; que compõe linhas de vida e devires reais, pontos de vista ativos e desterritorializações afirmativas" (CORAZZA, 2013, p. 205).

Isso significa que tenho pensado a docência não do ponto de vista mais tradicional, o qual pressupõe o docente como alguém que "sabe" - e, porque sabe, ensina -, mas sim como alguém que,

\footnotetext{
${ }^{3}$ Escrita do aluno Nani Marques Castiglio, em exercício proposto em aula a partir da questão: "que argumentos somos capazes de criar hoje para manter as artes nos curriculos escolares?".

${ }^{4}$ Embora a pesquisa trate especificamente da formação em artes visuais, as discussões com as quais ela opera podem ser ampliadas para outras licenciaturas, incluindo as áreas de música, teatro e dança.

Educação em Revista|Belo Horizonte|v.36|e219274|2020
} 
operando com disparadores os mais diversos - sobretudo os corporificados via palavras escritas/lidas e imagens -, é capaz de propor percursos formativos, deixando-se afetar pelo que encontra em meio ao caminho e, em seu exercício profissional, cria trajetos pedagógicos enquanto partilha de experiências diversas. Porque cria, também se cria nesse processo (CORAZZA, 2013), desviando-se de certa docência pautada pela "busca insana por 'competências' ou pela figura cristalizada da 'professora competente" (LOPONTE, 2003, p. 78-79).

A arte, por sua vez, é vista não necessariamente sob a égide de um fazer especial apartado do cotidiano, ou como um saber que se acumula, mas sobretudo como um gatilho que tira nosso pensamento de sua natural letargia (DELEUZE, 2006) ${ }^{5}$ e dá acesso a um corpo afetivo aquém do organismo estratificado (DELEUZE, 1981), possibilitando que nos relacionemos de outros modos conosco, com o mundo, com o próprio conhecimento (KASTRUP, 2009) ${ }^{6}$. Trata-se, pois, de se ocupar da "arte além da especificidade de uma disciplina ou de uma área de conhecimento", mas da "vida como obra de arte, relação estreita entre arte e modos de existência, entre arte e vida" (LOPONTE, 2013, p. 3).

Dialogando com Deleuze (1999) e na esteira teórica do que Kastrup (2001, 2009, 2016) pontua para o conceito de invenção e aprendizagem inventiva, a noção de criação é aqui compreendida descolada da noção cognitivista moderna de criatividade como solução única para problemas dados, bem como de certa concepção que confere a poucos "iluminados" o dom e a capacidade de criar objetos especiais (obras de arte, por exemplo), separados da vida comum. Baseados nesses autores, podemos afirmar que a criação/invenção não é

(...) algo raro e excepcional, privilégio exclusivo de artistas ou mesmo de cientistas. O interesse é pensar a inventividade que perpassa o nosso cotidiano e que permeia o funcionamento cognitivo de todos nós, do homem comum (KASTRUP, 2001, p. 19).

Justamente nessa direção apontada pela autora, permitam-me uma breve digressão. Há poucos meses, em uma viagem a trabalho que fiz a uma universidade comunitária do interior do sul do País, conheci a inspiradora obra do Sr. Zé, jardineiro dessa instituição. Conta-se que o Sr. Zé, após ter ganhado uma bolsa e ter concluído o curso de Bacharelado em Artes Visuais, conciliando estudo e trabalho no mesmo local, passou a produzir o que ele chama de intervenções land art pelo pátio onde desenvolve seu ofício (Figura 1), fazendo uso dos materiais que ele encontra em seu fazer diário, muitos dos quais outrora eram por ele recolhidos e descartados. Pedras, folhas e gravetos agora geram possibilidades de arranjo e composição que intrigam os passantes e os convidam a um olhar diferenciado sobre esses elementos investidos de outras camadas de sentidos pela ação intervencionista e performática do Sr. Zé, que mistura tal prática ao seu próprio cotidiano e ao cotidiano de quem frequenta os espaços por onde ele sensivelmente vive, se inscreve, trabalha.

\footnotetext{
${ }^{5}$ Para Deleuze (2006) “o problema não é dirigir, nem aplicar metodicamente um pensamento preexistente por natureza e de direito, mas fazer que nasça aquilo que ainda não existe (...). Pensar é criar, não há outra criação, mas criar é, antes de tudo, engendrar 'pensar' no pensamento" (p. 213).

${ }^{6}$ Entrevista disponível eletronicamente (consultar referências). 
Figura 1. Land Art (Sr. Zé, 2017).

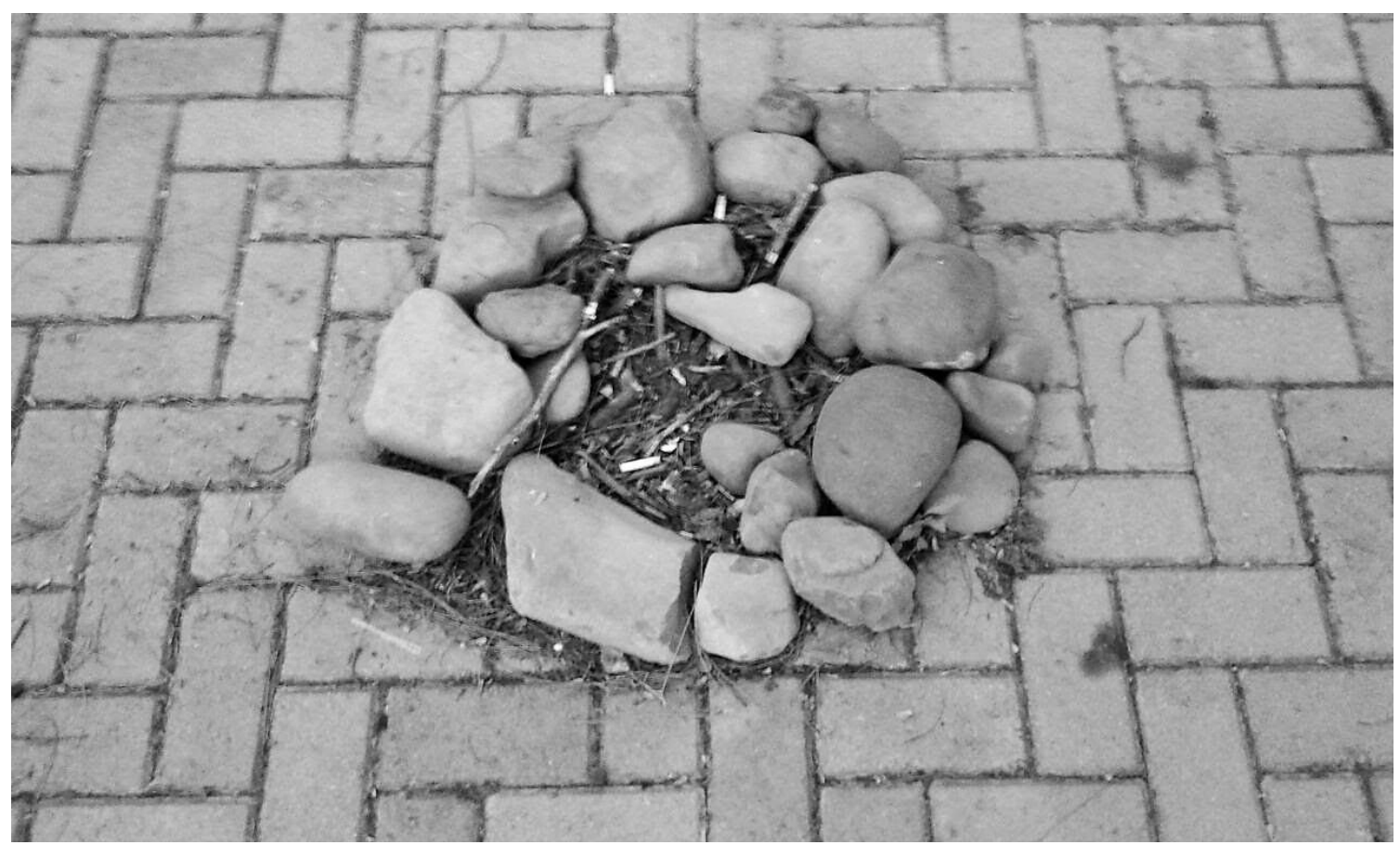

Fonte: Fotografia e arquivo pessoal do autor.

Convido essa potente imagem a compor este escrito, pois o produto do trabalho do Sr. Zé não é pensado necessariamente para uma galeria, museu ou grande evento artístico contemporâneo. Porém, traz em si algo caro para este texto, pelo menos em dois sentidos: o primeiro, em função da potência de um encontro inusitado que motiva o pensamento, que nos afeta na direção de movimentos até então impensados não fosse a efetivação de tal afecção, movimentos esses que constituem uma aprendizagem através do encontro com signos (DELEUZE, 2006), em que não necessariamente "um alguém" verticalmente ensina para que "outro alguém" aprenda exatamente o que foi ensinado, mas em que "um algo" ressoa; o segundo sentido relaciona-se a uma atitude de criação em meio à vida, de invenção e re-invenção cotidianas que abrem mão de certo produtivismo e pragmatismo cegos, operando no campo de uma resistência a modelos, padrões e formas de ser/fazer, de modo que se possam abrir brechas para um trabalho de povoamento sobre o mundo e, assim, sobre si mesmo - logo, uma reexistência.

Pensar uma docência ou uma criação de docências para o ensino das artes a partir das land arts do Sr. Zé, entre muitas possibilidades que elas nos lançam, pode denotar colocar em ação uma docência que se posiciona como alguém que (com e a partir da arte, por exemplo) cria rotas, percursos, trânsitos, espaços e condições para que encontros repletos de potência, para inumeráveis e impensáveis invenções, sejam possíveis. Não há controle sobre o que será criado, nem mesmo há certeza de que algo se produza, porque o foco está mais nos processos erráticos e nos múltiplos desdobramentos que eles possibilitam do que em um produto - ou uma aprendizagem - final.

Uma formação de docências, nessa perspectiva, tem como foco, portanto, o convite a açõespensamentos em sala de aula. Eles devem ensaiar tais demandas, antes de inferir uma lista de prescrições e metodologias referentes a planejamento, ensino e avaliação. Trata-se não de abandonarmos tais obrigações do exercício docente, mas de nos perguntarmos sobre que outros modos de planejar, ensinar e avaliar são possíveis. A arte como forma de pensamento e postura ético-estética diante da vida (LOPONTE, 2003, 2013) assim atravessa uma formação de docências que se sustenta no aprender, e não no ensinar; na produção de mundos e de saberes em multiplicidade, e não na listagem de conteúdos engessados que supostamente ofertariam uma realidade unívoca à espera de decifração.

O ensino das artes via imagens, sons, cenas e movimentos pode, sem dúvida, ocupar aqui um lugar importante de resistência às leituras rasas e simplistas que atravessam a vida, convidando a reexistências. Para isso, é preciso abrir mão de receituários, didáticas estanques e obviedades, centrando-se 
as práticas pedagógicas na arte como potência que nos incita a povoar nossos trajetos diários de disparadores, os quais convidem a experimentar outros estados (de investigação, de pensamento, de sensação, de posicionamento, dentre outros).

Ainda neste preâmbulo, cabe mencionar que me vejo diante de uma indagação. Em face das precárias condições em que se encontra grande parte das escolas brasileiras, bem como das atrocidades que mais recentemente as macropolíticas legisladoras ${ }^{7}$ de nosso país têm praticado no que se refere ao ensino das artes, impondo de modo autoritário e sem diálogo possíveis reformas as quais, se aprovadas, podem colocar em xeque anos de conquistas tangentes ao campo das artes na educação básica, que estratégias de resistência e de re-existência - ou seja, de povoamento de ações e ideias singulares que, de algum modo, criem novos argumentos para que as artes se sustentem nos currículos escolares - têm sido possíveis?

A escrita que se encontra como epígrafe desta seção do texto, portanto, nos ajuda a ponderar: por que ensinamos/aprendemos artes? Por que lutamos para manter essa área como componente da formação escolar de crianças, jovens e adultos? Que percursos pedagógicos temos criado em nossas práticas enquanto docentes e que povoamentos de ações e ideias singulares temos produzido nos espaços/tempos de que dispomos para trabalhar?

Sem dúvida as respostas para tais questões não são únicas, nem definitivas, mas pensar sobre elas é também pensar sobre o que temos feito de nós mesmos diante dos contextos em que atuamos. É sustentar uma postura afirmativa diante da vida e da profissão que nos coloca não como vítimas de um suposto poder autoritário que nos engole, mas como indivíduos capazes de resistir e re-existir em meio ao que nos chega como imposição, seja do ponto de vista das leis, dos currículos, das diretrizes, normas, políticas, ou mesmo dos espaços arquitetônicos, corpos e instituições que configuram os imensos agenciamentos da educação e das artes, povoando-o entre suas brechas de formas alternativas de vida.

\section{O QUE PODE O ENSINO DAS ARTES NA CONTEMPORANEIDADE?}

No Brasil, a obrigatoriedade do campo da arte como componente curricular na educação básica é muito recente. Tal determinação data de 1996, ano de publicação da Lei de Diretrizes e Bases da Educação Nacional (LDB - Lei no 9.394), lei essa que está em vigência até a atualidade no território nacional.

Nesses mais de vinte anos, inúmeras foram as alternativas didáticas/metodológicas/pedagógicas pensadas por uma diversidade de autoras e autores, professoras e professores, pesquisadoras e pesquisadores, sobretudo no que concerne ao aprendizado da arte nos ambientes formais de ensino. Não está no escopo deste texto enumerá-las, tampouco analisá-las criticamente; contudo, vale dizer que o campo de discussões que se mostrou atuante nesse espaço de tempo, especialmente no ambiente acadêmico, possibilitou inúmeras conquistas, contribuindo para que a arte fosse legitimada como disciplina a ser ministrada nas escolas de ensino fundamental e médio.

Considerando que muitas conquistas ainda são apenas possibilidades distantes, e que nesse espaço de tempo a própria arte demonstrou significativas mudanças, ampliando consideravelmente alcances e limites procedimentais e estéticos, resta pensarmos: o que pode o ensino das artes na contemporaneidade?

Do mesmo modo que, atualmente, para produzir o cotidiano em que vivemos, diversas esferas sociais lançam mão de estratégias visuais, sonoras, performativas e ficcionais que até pouco tempo eram arraigadas apenas aos limites artísticos, percebemos também que, em meio a esse contexto, a arte não parece mais se comprometer somente com o que é aprazível, belo, esteticamente agradável e

\footnotetext{
${ }^{7}$ Não cabe aqui discorrer acerca das referidas macropolíticas; mas podemos mencionar como exemplo a recente homologação da Base Nacional Comum Curricular (BNCC) para a Educação Infantil e para os Ensinos Fundamental e Médio, bem como a conhecida "Reforma do Ensino Médio".

${ }^{8}$ Tal indagação acompanha as discussões desenvolvidas atualmente pelo Grupo de Estudo e Pesquisa ARTEVERSA, liderado pela Profa. Dra. Luciana Gruppelli Loponte e do qual faço parte como membro pesquisador. Parte da produção do grupo pode ser visualizada aqui: <https://www.ufrgs.br/arteversa/>, destacando-se especialmente a seção "Textos para abrir uma conversa", no qual o Grupo tem se dedicado a lançar textos curtos que convidam a pensarmos em novos argumentos para a permanência do ensino das artes nos currículos escolares e da formação universitária.

Educação em Revista|Belo Horizonte|v.36|e219274|2020
} 
apaziguador. Basta uma busca rápida pela web para percebermos que a arte, que se confunde cada vez mais com a vida, tem nos lançado inúmeras questões as quais dizem respeito a todas e todos nós, seres humanos, à nossa existência e permanência no planeta, aos modos como lidamos com nossos sistemas de crenças, com nossas concepções políticas, com nossos corpos, com nossas formas de ver o mundo, a morte, o universo, o outro etc.

A arte contemporânea visa produzir experiências de estranhamento. A pergunta que ela suscita não é tanto "isto é belo?”, mas “isto é arte?”. Mais uma vez, estamos diante da incerteza. Mas insiste a força do enigma, a potência do que não é conhecido, sabido e esperado. Somos forçados a pensar, a ir além. Acolher e habitar incertezas é uma questão de aprendizagem. Aqui, não se trata da aprendizagem mecânica ou intelectual, nem daquela que se baseia na transmissão de informações. A educação não é uma questão de informação, nem de explicação, nem de formação de opinião. A questão aqui é a da aprendizagem inventiva, que inclui a capacidade de problematizar, de criar novos problemas. Trata-se de instaurar uma política cognitiva da invenção (KASTRUP, 2016, p. 4).

De modo bastante paradoxal, encontramos - mesmo diante de toda essa complexidade - o ensino da arte sendo tratado como algo desnecessário ou sem conteúdo, como algo decorativo ou facilmente dispensável, como algo que pode ser trabalhado por qualquer profissional sem habilitação, que fará qualquer atividade sem o empenho e a seriedade que esse campo requer e merece. Nesse sentido, é muito comum, entre minhas alunas e meus alunos, que antes de produzirem seus projetos de ensino de estágio observem turmas de ensino fundamental e ensino médio em escolas públicas, o relato de práticas completamente descontextualizadas sendo efetuadas nas escolas, como o desenho livre, a folha mimeografada para pintar, a fabricação de objetos utilitários padronizados e sem engajamento processual, investigativo, ou mesmo a mínima preocupação estética.

Se nos descolarmos de qualquer julgamento moral acerca de tais ações, perceberemos que nenhuma delas (o desenho livre, a folha para pintar, o objeto utilitário, ou qualquer outra) é boa ou ruim em si mesma. Contudo, podemos, em primeiro lugar - retomando a complexidade em que se apresenta o campo artístico na contemporaneidade -, observar as inúmeras potencialidades de invenção, ação e pensamento que se perdem ou se deixam de lado na escola ao não operarmos com a arte considerando toda sua força. Em segundo lugar, pensarmos: que desenho livre é esse que estamos propondo/fazendo? Que folha para pintar é essa e que objeto utilitário é esse? Que formas de desenho, de pintura, de fabricação de objetos são possíveis hoje e nos futuros que a partir deles podemos inventar? Como podemos ampliar as múltiplas e variadas possibilidades de desdobramento de um desenho, de uma pintura, de um objeto? Não é novidade que nosso cotidiano está rodeado por imagens, sons, artefatos, ideias e realidades que nos chegam através dos mais variados meios e contextos e que podem ser arranjados como sinalizadores de caminhos nas rotas de aprendizagem por nós invencionadas.

Falar de ensino das artes na contemporaneidade, portanto, é falar de um lugar privilegiado para que experiências e experimentações diversas sejam possíveis, seja com a arte legitimada historicamente como Arte (com letra maiúscula), ou com a arte (com letra minúscula) que atravessa o cotidiano, a existência, o lar, as relações, as redes sociais, o consumo. É um lugar para mapear os saberes produzidos ao longo do tempo, mas também para produzir novos saberes, saberes outros, saberes-semsaber. Do mesmo modo, é um lugar (por que não?) em meio ao conhecimento já traduzido em palavras e imagens, que pode abrir brechas para que sensações e afetos ilegíveis, inaudíveis, inexplicáveis e impensáveis nos tomem e nos possibilitem experimentar outros lugares, olhares, mundos, outras possibilidades.

Sem dúvida não há um receituário, um "como" fazer. Tampouco há um "como" formar professores para seguirem tais perspectivas. Nem seria essa a intenção aqui, se isso fosse possível. O que há são horizontes formativos, ou seja, formas de criarmos condições para que professores em formação se ensaiem e, em meio ao que encontram em suas rotas errantes, capturem-no como instrumental para operar e continuar incessantemente se experimentando, criando, resistindo e re-existindo. Tanto o arranjo de noções a seguir, como a proposta relatada na última parte deste texto dizem desses possíveis horizontes formativos que desejam aqui nada mais do que contornos provisórios. E que o possível leitor possa, com eles ou a partir deles, inventar outros mundos tendo a arte menos como um conteúdo a 
ensinar e mais como uma forma de pensamento, como um vetor de operação e mobilização de novas realidades por vir, de outros futuros.

\title{
UM ARRANJO DE NOÇÕES: CRIAÇÃO, RE-EXISTÊNCIA, POVOAMENTO E ARTE
}

\begin{abstract}
Não há mais dúvidas de que todas as pessoas são inatamente criadoras, independentemente de sua formação cultural, de sua atividade, de sua origem racial ou geográfica. O que nos impede de exercer o nosso desejo criativo? A concepção de nós mesmos, como um ser acabado e estável, agarrado a uma ideia de eu, tal como a tábua de salvação no meio do mar, é um empecilho para nos lançar. A vivência pode significar um caminho aberto para o desconhecido, ampliando a nossa consciência (DERDYK, 2010, p. 17).
\end{abstract}

Mobilizados pela ponderação de Derdyk, iniciemos o proposto arranjo de noções pela palavra criação. O que é criar? O que nos vem à mente quando pensamos em criação? Conforme já referido anteriormente, tentemos por um instante nos desvincular dos estereótipos modernos que colam a ideia de criação à de criatividade para, em meio a isso, pensarmos por que criar se vincula às resistências/re-existências e aos povoamentos articulados à arte, segundo o que sugiro neste subtítulo.

Nessa seara, Gilles Deleuze e Virgínia Kastrup (em publicações já mencionadas) ajudam-me a pensar uma criação que não pertence apenas a alguns sujeitos racionais, autocentrados, ideais e donos de si, os quais criam com maestria certos objetos especiais que são geralmente considerados obras primas, obras de arte separadas da vida ordinária, ou seja, para serem apreciadas pelo público comum (que, segundo tal concepção, não cria, não produz arte).

Gilles Deleuze (1999) se pergunta: "o que significa ter uma ideia? O que acontece quando dizemos: 'Ei, tive uma ideia'?” (p. 2). À guisa de responder tal problemática, Deleuze e Guattari (2011) apontam que nunca temos uma ideia em geral. Uma ideia é sempre contingente, destinada a um domínio específico.

\begin{abstract}
Trata-se de uma ideia em pintura, ou de uma ideia em romance, ou de uma ideia em filosofia, ou de uma ideia em ciência. E obviamente nunca é a mesma pessoa que pode ter todas elas. As ideias, devemos trata-las como potenciais já empenhados nesse ou naquele modo de expressão (...). Em função das técnicas que conheço, posso ter uma ideia em tal ou tal domínio, uma ideia em cinema ou uma ideia em filosofia (DELEUZE, 1999, p. 2).
\end{abstract}

Ao afirmar isso, o autor coloca em xeque certa noção de genialidade. Embora seja raro ter ideias, não seja algo muito comum, segundo ele - já que vivemos mais reproduzindo o que aprendemos do que criando algo novo -, todos podemos ter ideias. Como afirma Kastrup (2016), "múltiplos e variados, os processos de invenção não se restringem à arte, à ciência, à tecnologia e à filosofia, mas fazem parte do cotidiano (...) atravessando subjetividades e domínios cognitivos” (p. 3).

Nesse sentido, a criação de que trato aqui - fazendo novamente menção à obra do Sr. Zé apresentada anteriormente - se espraia pela vida e pelos múltiplos contextos dos quais participamos e nos quais atuamos, ligados ou não à arte e às áreas entendidas pelo senso comum como criativas. Certamente criamos em arte, mas também criamos na docência, na ciência, na filosofia, nas atividades mais prosaicas do dia a dia. Conforme as demandas que surgem, dentre muitas possibilidades, podemos escolher entre reproduzir o que já sabemos, ou criar algo novo, um caminho outro ou "um povo que ainda não existe" (DELEUZE, 1999, p. 14), ideia que dá embasamento à noção de "povoamento" com a qual tenho trabalhado e que está no título deste texto.

As ideias surgem apenas mediante necessidades. "É preciso que haja uma necessidade, (...) do contrário não há nada. Um criador não é um ser que trabalha pelo prazer" (DELEUZE, 1999, p. 3) ou porque tem um dom, porque é iluminado. "Um criador só faz aquilo de que tem absoluta necessidade" (p. 3), ou seja: seria possível afirmar que não somos nós que temos as ideias, que criamos, mas são as ideias, os atos de criação que "nos têm", que criam ressonâncias em nós, de acordo com o que nos afeta e nos arrasta o corpo, de acordo com o que nos chega e - enquanto corpo, enquanto presença que somos - filtramos e enviamos como uma flecha em velocidade infinita para outras direções? Se, conforme o exposto por Deleuze (1999), um pintor é quem tem uma ideia em pintura, um cineasta uma ideia em cinema, e assim por diante, poderíamos pensar que um professor é aquele que tem ideias em docência? 
Criar, portanto, seria não inventar uma existência nova, mas re-existir. Existir de outro modo dentro da própria existência. Resistir das formas dadas, prévias, prontas de pensamento/ação para encontrar outras estratégias, outros funcionamentos para aquilo que já existe, "fazendo emergir atitudes de engajamento e participação que procuram originar estratégias de construção de um mundo comum" (KASTRUP, 2016, p. 3). Isso significa escolher o caminho das incertezas e não das certezas, o caminho da invenção de problemáticas que geram outras problemáticas (problematização), e não da criatividade no seu sentido mais comum, como "elaboração de soluções originais para os problemas já dados" (p. 4).

Apresentar novos problemas, ou seja, problematizar, é resistir ao saber que já está pronto e à recognição, fazer o pensamento re-existir criando bifurcações e fugas do senso comum e da paralisia reprodutiva. Isso significa acolher e habitar a incerteza, sendo que "nem sempre é fácil e trivial abrir mão da tendência à recognição, quebrar esquemas sensório-motores, conexões mecânicas de percepção-ação (KASTRUP, 2016, p. 4).

Nessa perspectiva, ensinar/aprender algo excede simplesmente conhecer o que não se conhecia, ou decifrar, ler um mundo que já estaria pronto esperando que a ele meramente nos adaptássemos; mas se amplia para inventar, criar, compor outros arranjos possíveis com o que vai afetando nosso corpo pelo caminho, cunhar universos dentro do universo, produzir rotas que possibilitem experiências diversas, desestabilizar o que parecia estável, desdobrar outras possibilidades no que parecia fechado, pois "aprender não é adaptar-se a um meio ambiente dado, a um meio físico absoluto, mas envolve a criação do próprio mundo" (KASTRUP, 2001, p. 21).

A obra Traças, pontos e linhas - Living Animals (Figura 2), da artista carioca Fábia Schnoor (2012), ajuda-nos, de algum modo, a compor o arranjo criação-resistência/re-existência-povoamentoarte aqui proposto, como plataforma de invenção e pensamento sobre formação/ensino das artes.

Os furos feitos pelas traças nas páginas de um antigo livro sobre animais foram marcados com pontos, exatamente onde estavam originalmente, em uma nova folha de papel. Esses pontos foram interligados por linhas, sugerindo possíveis percursos das traças e desenhando volumes e planos. Relacionando-se essa nova ocupação gráfica e geométrica à imagem orgânica do animal na página do livro, são criadas outras relações entre estes dois corpos no espaço (SCHNOOR, 2012, s/p).

Figura 2. Traças, pontos e linhas - Living Animals.

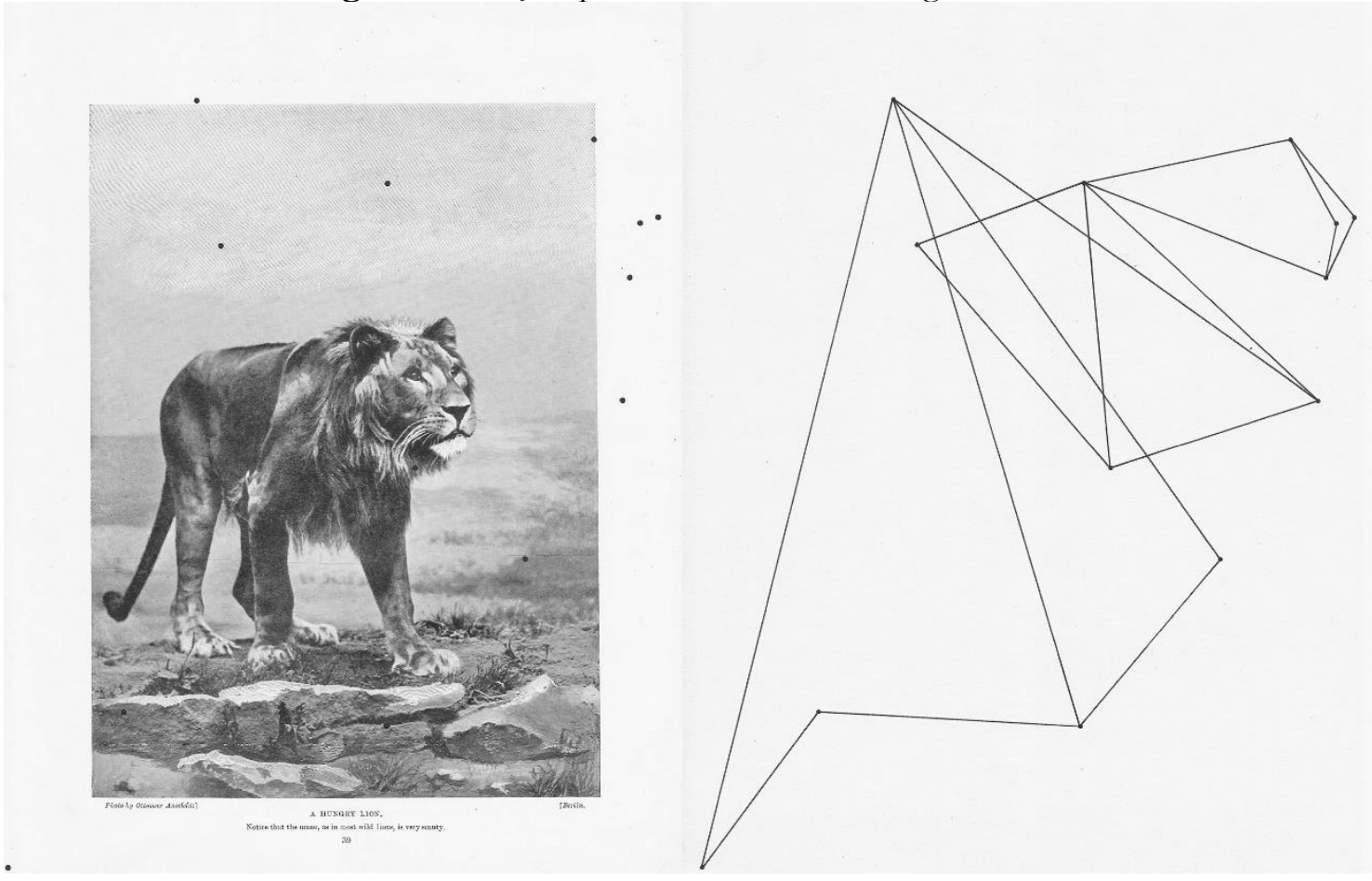

Fonte: Schnoor (2012). 
Podemos dizer que a artista, sobre/com algo que parecia dado (um livro de história natural), cria outros trânsitos, outros percursos, outras entradas não usuais pelo/no/com o material que utiliza para sua obra, evidenciando que as coisas (uma página em branco, um espaço, um texto, uma imagem etc.) não são nada em si, mas sim resultantes das maneiras que utilizamos para ocupá-las, para nos relacionar com elas. As coisas são os trajetos que fazemos com e sobre elas e as composições que vamos propondo com outras vidas, com outros objetos, com outros ditos, silêncios e vazios.

A traça cursa o livro de um modo muito diferente de um certo leitor comum, que abre o livro e o percorre com os olhos sempre da esquerda para a direita. A traça é despretensiosa e desrespeitosa em sua não-leitura, em seu passeio pelas páginas. Fábia é desrespeitosa de um desrespeito inventivo com o feito da traça, já que poderia ter simplesmente jogado o livro fora. Fábia não se desfaz do livro, mas re-existe diante do objeto, fazendo-o do mesmo modo re-existir. A partir de uma contingência específica que se impõe a ela, cria uma nova existência, re-existe e insiste no que parecia dado, pronto, perdido. Povoa as páginas soltas de outras possibilidades de sentidos, de outras linhas e vetores que convidam o pensamento a outras dimensões que vazam da única possibilidade de leitura de uma "história natural", por exemplo.

Daí uma ponderação que parece importante: resistir não é revolucionar, não é fugir daquilo que nos chega. Re-existir também não é existir novamente, começar uma vida do zero. Mas, nesta existência, por ela, com ela, nela, o que é possível? Que povoamentos somos capazes de provocar? Povoamentos de ideias, de sensações, de palavras escritas/lidas e imagens que nos ajudam a escapar do senso comum e dos clichês ligados à arte e à docência, a criar estratégias de guerrilha para o que se impõe como norma única, como prescrição inequívoca.

Posto isso, podemos pensar que, assim como a palavra criação é coberta de clichês, a palavra arte também pode ser reposicionada de modo a ser ponderada, conforme afirmado algumas vezes ao longo deste artigo - não tão distante da vida e, por conseguinte, da própria formação, da própria docência: para além de um saber estanque, um lugar, um território ou um plano que permite olhar e reinventar nossos percursos formativos.

De acordo com Deleuze e Guattari (1992), junto com a filosofia e a própria ciência, a arte seria uma das três grandes formas de pensamento que teriam como objetivo principal "enfrentar o caos, traçar um plano, esboçar um plano sobre o caos" (p. 253) e não meramente representar o mundo. Sendo ela o ato de capturar forças e apresentá-las como blocos de sensação (perceptos e afectos) que nos abrem acesso a um corpo afetivo (no contraponto da organização autoritária, significante, rígida do corpo), e não meramente a ação de inventar formas - o músico, por exemplo, seria aquele que capturaria forças inaudíveis e as tornaria audíveis fazendo uso de meios e técnicas específicas -, o artista trabalharia muito mais na limpeza dos inúmeros clichês que estão presentes em seus materiais de trabalho, seu ateliê e seu próprio corpo, do que propriamente criando algo único e original, nunca antes visto (DELEUZE, 1981).

É um erro dizer que o pintor está diante de uma superfície branca. A crença figurativa advém deste engano: de fato, se o pintor estivesse diante de uma superfície branca ela poderia reproduzir um objeto exterior que funcionasse como modelo. Mas não é assim. O pintor tem muita coisa na cabeça, ou a sua volta, ou no atelier. Portanto tudo o que há na sua cabeça ou à sua volta já está na tela, mais ou menos virtualmente, mais ou menos atualmente, antes que ele comece a trabalhar (DELEUZE, 1981, p. 45).

Se vincularmos essa noção à formação de professores, poderíamos pensar que a criação de um percurso formativo seria muito mais a limpeza dos inúmeros clichês que se acumulam historicamente em relação à docência do que propriamente o exercício de aprender um jeito único de ser (formas prontas do que significaria ser um bom professor) ou de fazer (fórmulas mágicas para dar uma boa aula, passo a passo). Como podemos criar nossos planejamentos de aula e projetos de ensino como o esboço de um plano sobre o caos? Como podemos apresentá-los como blocos de sensações que convidam o corpo/pensamento dos estudantes a experimentar outros estados, menos duros, menos baseados na razão e na significação, no produtivismo e na necessidade de utilidade pragmática que assolam nossos dias? Que forças inaudíveis e não visíveis temos conseguido capturar em nossas aulas, junto de nossos estudantes? 
Conforme afirma Kastrup (2016), arte seria "uma das maneiras de trabalhar na direção da problematização e da invenção de si e do mundo" (p. 4), concorrendo para que se modifique nossa política cognitiva (ainda pautada no esquema platônico da representação ${ }^{\natural}$ ); ou seja, a forma como estamos no mundo e entramos em relação com o conhecimento - em suma, nossa forma de cultivo de nós mesmos (KASTRUP, 2009). Segundo Kastrup (2016), ela "não é a única estratégia" para que isso seja possível, "mas fornece efetivamente condições para evitar automatismos perceptivos", (p. 4), visto que

A experiência estética pode ser de difícil apreensão, mas, por ter um caráter inquietante, atrai e mesmo obriga a retornar a determinada imagem diversas vezes, interrompendo e voltando, em um vaivém entre o chamado da obra e o desejo de ir além que ela suscita. A experiência estética tem, assim, o potencial de desencadear processos de aprendizagem (KASTRUP, 2016, p. 4).

Nessa perspectiva, a autora propõe que o conhecimento, no que tange à arte, não é acumulativo nem transmissível, mas que só é possível pensar em ensinar/aprender arte se entendemos ensino/aprendizagem como compartilhamento de experiências, ou melhor, como criar condições para que a experiência (com arte) seja possível.

O que temos feito com a nossa própria vida e com nossa atuação profissional? Como temos existido e re-existido? Sobretudo, como tais questionamentos podem ser pensados na escola e na universidade, junto de nossos alunos, povoando/ocupando a arte como um território para partilhar experiências e sustentar um campo de problematizações (KASTRUP, 2009) e menos como uma listagem de conteúdos e/ou fazeres muitas vezes descolados de nossos contextos cotidianos?

A arte a que aqui me refiro não seria vinculada à concepção que a confina em suntuosos museus, emoldurada como objetos seletos e apartada da vida cotidiana; mas, de acordo com uma concepção mais ampliada respaldada por Loponte $(2003,2013)$ na esteira teórica de filósofos como Nietzsche e Foucault e pelo próprio Sr. Zé, se amalgaria à arte de nós mesmos, à possibilidade de criarmos resistências/re-existências em nossa existência, a uma postura artística diante da vida e de povoamentos afirmativos dos territórios de subjetivação, incluindo o da docência. Povoamento como ocupação de certo espaço-tempo com composições de palavras escritas/lidas e imagens que convidam ao pensamento enquanto criação, povoamento como invenção de rotas que abrem possibilidades de futuros e de aprendizagens. Povoamento enquanto criação, portanto. Criação que é sempre resistência/re-existência e insistência.

\title{
CONSIDERAÇÕES FINAIS
}

\section{Um horizonte formativo: desaprender formas prontas entre palavras escritas/lidas e imagens}

\author{
O essencial é saber ver - \\ Mas isso (triste de nós que trazemos a alma vestida!). \\ Isso exige um estudo profundo, \\ Uma aprendizagem de desaprender... \\ Procuro despir-me do que aprendi \\ Procuro esquecer-me do modo de lembrar que me ensinaram \\ E raspar a tinta com que me pintaram os sentidos, \\ Desencaixotar as minhas emoçoes verdadeiras, \\ Desembrulhar-me e ser eu...
}

\footnotetext{
${ }^{9}$ Sílvio Gallo (2012) ajuda-nos a pensar como o esquema platônico da representação infere os modos como entendemos a aprendizagem até hoje em nossa cultura ocidental. Pondera o autor: "Platão afirma que o conhecimento é uma função da alma racional. Como esta alma é eterna, ela participa do 'mundo das ideias' (que é diferente do mundo material, sensível, cópia imperfeita daquele) e, assim, a alma racional participa das ideias, as conhece, as contém em si. A questão é quando a alma se encarna em um corpo que nasce, dadas as limitações do material, ela se esquece de todas as ideias. Ao longo da vida, a alma vai, aos poucos, se 'recordando' daquilo que já sabia. O aprender constitui-se, pois, numa recognição, em voltar a saber algo que já se sabia. Esse processo pode ser 'acelerado' e aprimorado com treino - o processo educativo - e culmina com o exercício da Filosofia, o conhecimento das puras ideias" (p. 1).

Educação em Revista|Belo Horizonte|v.36|e219274|2020
} 
Tenho pensado que se faz cada vez mais urgente encontrarmos dispositivos para desaprender o que é arte e mesmo desaprender o que é educação, ensino, docência, formação. Desaprendermos a nós mesmos de modo a nos tornarmos sempre outros. O exercício de escrita deste texto e da própria pesquisa que lhe dá origem trazem um pouco dessa vontade, ou seja, por meio de intercessores diversos - autores, imagens, encontros - forçar formas outras de pensar as noções aqui presentes, desaprendê-las entre criação e docência, com elas resistir e fazê-las re-existir, povoá-las de outras possibilidades de invenção. Desaprender não é esquecer o que já foi produzido durante anos e até séculos nas referidas áreas, mas encontrar formas sempre novas, novas composições, novas operações e funcionamentos para aquilo que se põe em jogo diante de nós, para aquilo que vamos encontrando em meio às nossas trajetórias formativas.

Não há e não deve haver formas prontas para pensar um currículo, uma aula de artes, uma formação, uma vida. Há sempre possibilidades de existir e de resistir/re-existir, lugares inexplorados a serem povoados quando tudo já parece ter sido feito, pensado, ocupado, estabelecido, criado.

Um horizonte formativo no qual tenho apostado enquanto professor de futuros professores de artes (visuais, no caso) tem sido o da utilização, em minhas aulas e pesquisas, de imagens e textos como artefatos que convidam ao pensamento e, por sua vez, à criação, e não somente como anteparos de decodificação, no sentido mais estrito que essa palavra pode ter. Ou seja, trata-se de ler transcriadoramente (CORAZZA, 2013), implantando outros cursos de sentidos e significados àquilo que se lê, entre leitor e texto; trata-se de escrever não porque se tem certeza, mas justamente porque não se sabe e se quer ensaiar o pensamento em outras direções que não apenas as amparadas pela razão (LARROSA, 2016) e operar com imagens mais além da ilustração, ou da representação de ideias faladas/escritas (OLIVEIRA; CHARRÉU, 2016). Dessa forma,

(...) ver o que os outros já viram, mas ainda não enxergaram, mostrar o que, embora seja visível para os outros, permanece oculto. Ler o que os outros já leram, mas ser capaz de, a partir dos mesmos referenciais, dizer o que ninguém disse ou dizer de uma outra maneira. Ou, ainda, o que eu sou capaz de dizer a partir do que o autor disse? (OLIVEIRA; CHARRÉU, 2016, p. 373).

Diante do exposto até aqui, de modo a finalizar este texto, gostaria de compartilhar uma das ações recentes do projeto de pesquisa em questão que, por sua vez, elucida o proposto horizonte formativo com o qual tenho operado junto às acadêmicas e aos acadêmicos em formação. Trata-se da ação artístico-educacional Postais para o Futuro ${ }^{10}$.

Mediante as seguintes questões mobilizadoras: "A partir de suas vivências com a disciplina de Estágio Curricular Supervisionado (passadas ou presentes) em certo curso de formação, o que você diria para um@ estagiári@ do futuro? Que imagens e escritas deixaria - como uma mensagem-arsenal que atravessa o tempo - para que estagiári@s que estão por vir possam se munir de ideias disparadoras?”, professoras e professores em formação e/ou já atuantes, das mais diversas instituições de ensino (superior e de educação básica) do País e das mais diversas áreas (não necessariamente apenas das artes), criam postais baseados nas vivências decorrentes de suas inserções como estagiários em diversos contextos educacionais/escolares. A pretensão é a de que esse material, advindo de inúmeros lugares institucionais/geográficos, e trazendo em si as mais variadas concepções de docência, escola, educação, formação etc., seja coletado por pelo menos dez anos, formando uma espécie de cápsula do tempo onde será possível mapear compreensões que povoam uma época, um recorte, um agenciamento coletivo (DELEUZE; GUATTARI, 2011) de vozes, ideias, práticas em movimento e em plena artesania.

A ideia é que os participantes criem ou se apropriem de imagens, bem como criem ou se apropriem de escritas e as ponham em relação de tensionamento e/ou diálogo, "colocando em funcionamento uma outra máquina de pensar e criar, de estudar e escrever, de ensinar e aprender, de ser professor e professora" (CORAZZA, 2013, p. 97).

\footnotetext{
${ }^{10}$ Mais informações e o acervo da ação disponíveis no blog: < https://postaisparaofuturo.wordpress.com/>.
} Educação em Revista|Belo Horizonte|v.36|e219274|2020 
Os postais revelam, através de imagens e escritas que se dão a ver/ler, endereçadas a sujeitos sem face e sem nome, camadas de tempos e de afetos, de redes de conexões plurais e de uma constelação de visualidades e palavras que não querem se impor como conselhos ou verdades, mas como potência para infinitas outras multiplicidades experimentativas.

Daí decorre uma docência-pesquisa que reconhece que só funciona, isto é, torna-se ativa e afirmativa, se, além de criar uma nova sensibilidade, também lida com as problemáticas contemporâneas; transformando-se numa educação nunca definitivamente fixada, jamais esgotada, intempestiva (...), a favor de um tempo por vir (CORAZZA, 2013, p. 98).

Assim, a escrita produzida para tais artefatos e a leitura que se oferece na ação de enviar um postal a um futuro incerto estão de acordo com o proposto por Skliar (2014), para quem leitura e escrita comungam de um sentido: o de fazer vacilar o Eu como categoria inquestionável. A escrita qualifica-se "como convite a ir além de si mesmo, a sair, a livrar-se da própria modorra, um convite para abandonar o relato repetido, a identidade de si como centro do universo" (p.109).

Já a leitura, relacionada a essa primeira, se configura como uma experiência em que o "leitor põe à prova sua crença identitária na alteridade da leitura: a cada fragmento, a possibilidade de uma pergunta que começa sendo exterior e se interioriza até confundir alteridade com intimidade" (SKLIAR, 2014, p. 85).

Os textos produzidos para os postais (sua leitura e sua escrita) juntamente às visualidades que convidam e possibilitam pensamentos e ideias em/sobre educação, docência, escola, formação etc., nessa perspectiva, são um compilado de afetos que, se por um lado procuram significar algo, dizer alguma coisa, cristalizar possibilidades, por outro estabelecem apenas um espaço informe onde nada é ainda, onde tudo está em vias de ser - um Fora nos diria Levy (2011) a partir de seus estudos acerca desse conceito-, onde há apenas possibilidades e virtualidades que se atualizam somente quando os postais encontram ressonância em algum leitor.

Considerando as visualidades, leituras e escritas em forma de postais, nunca teremos uma escrita ou uma aprendizagem plenamente acabada, a compreensão máxima de uma noção, o estabelecimento fixo de qualquer verdade ou uma única imagem que dê conta do todo de uma experiência formativa. Teremos, sempre, uma gigantesca malha, um tecido composto por uma infinita extensão de possibilidades, de cruzamentos, nós, tensões, enlaces entre imagens e palavras. Multiplicidade de multiplicidades, um e......e.. (DELEUZE; GUATTARI, 2011) que configura uma cartografia heterogênea entre os tantos "isto, ou aquilo" com os quais nos deparamos diariamente. Desse modo, entendemos que "escrever (com imagens, no caso dos postais) nada tem a ver com significar, mas com agrimensar, cartografar, mesmo que sejam regiões ainda por vir” (DELEUZE; GUATTARI, 2011, p.19, acréscimos meus).

Entende-se, portanto, que a proposta dos postais aqui relatada pode ser o povoamento de um território informe, movediço, um lugar de resistência que propõe re-existências na medida que nos convida a olhar para o que tem sido feito/pensado/afirmado e sustentar a criação de outras ideias, sendo que

(...) o mais importante é nos interrogar se tudo o que dissemos, até então, sobre pedagogia, currículo, escola, aluno, professor é tudo o que podemos dizer; se tudo o que vimos, até agora, é, de fato, tudo o que podemos ver; se tudo o que pensamos é tudo o que podemos pensar; se tudo o que sentimos é tudo o que podemos sentir; e assim por diante (CORAZZA, 2013, p. 98).

Seguindo a epígrafe assinada por Caeiro, que inicia esta seção, poderíamos dizer que os postais se abrem para aprendizagens de desaprender, já que demonstram como, naquilo que poderia ser dado como estanque, fixo, estabelecido (a escola, a formação, o currículo, a arte, ou mesmo em um texto ou uma imagem), sempre há uma nova ideia a ser ponderada, uma nova ação a ser performada, uma nova escrita a ser lida, uma nova imagem a ser produzida, pensada, imaginada. Novas resistências e reexistências, novos povoamentos entre docência e criação, vida e arte. 


\section{REFERÊNCIAS}

BRASIL. Lei n. 9.394, de 20 de dezembro de 1996. Estabelece as diretrizes e bases da educação nacional. Disponível em: <http://www.planalto.gov.br/Ccivil_03/leis/L9394.htm>. Acesso em: 10 jan. 2019.

CAEIRO, A. O essencial é saber ver, mas isso exige uma aprendizagem de desaprender. Disponível em: <https://www.pensador.com/frase/MTA4OTQ3Ng/>. Acesso em: 15 fev. 2018.

CORAZZA, S. M. O que se transcria em educação? Porto Alegre: UFRGS, Doisa, 2013.

DELEUZE, G.; GUATTARI, F. Mil platôs: capitalismo e esquizofrenia, Trad. A. L. de Oliveira, A. Guerra e C. P. Costa, 2.ed. Rio de Janeiro: Ed. 34, 2011. v.1.

DELEUZE, G.; GUATTARI, F. O que é a filosofia? Trad. B. Jr. \& A. A. Muñoz, Trad. Rio de Janeiro: Ed. 34., 1992.

DELEUZE, G. Francis Bacon: logique de la sensation. Trad. S. Ferraz \& A. C. Malufe, Paris: Aux Éditions de la Différence. 1981. Disponível em: <http://conexoesclinicas.com.br/wpcontent/uploads/2015/12/deleuze-francis-bacon-logica-da-sensacao-1.pdf>. Acesso em: 10 maio 2018.

DELEUZE, G. O ato de criação. Trad. J. M. Macedo. São Paulo: Folha de São Paulo, 1999.

DELEUZE, G. Diferença e repetição. 2. ed. Rio de Janeiro: Graal, 2006.

DERDYK, E. Formas de pensar o desenho: desenvolvimento do grafismo infantil. 4. ed. rev. Ampl. Porto Alegre: Zouk, 2010.

GALLO, S. As múltiplas dimensões do aprender. In: CONGRESSO DE EDUCAÇÃO BÁSICA: APRENDIZAGEM E CURRÍCULO. 2012. Florianópolis. Anais online [...]. Florianópolis: UFSC, 2012. $\quad$ p. 1-10. Disponível em: <http://www.pmf.sc.gov.br/arquivos/arquivos/pdf/13_02_2012_10.54.50.a0ac3b8a140676ef8ae0dbf 32e662762.pdf>. Acesso em: 10 mar. 2018.

KASTRUP, V. Educação e invenção em tempos de incerteza. In: VOLZ, J.; PRATES, V. (Orgs.). Incerteza viva: processos artísticos e pedagógicos. BIENAL DE SÃO PAULO, 32. Anais [....] São Paulo: Fundação Bienal de São Paulo, 2016.

KASTRUP, V. A aprendizagem inventiva [arquivo de vídeo]. 2009. Disponível em: <https://www.youtube.com/watch?v=Sz7-cLdgsVk>. Acesso em: 15 jan. 2019.

KASTRUP, V. Aprendizagem, arte e invenção. Psicologia em estudo. Maringá, v. 6, n. 1, p. 17-27, jan./jun., 2001.

LARROSA, J. O ensaio e a escrita acadêmica. In: CALLAI, C.; RIBETTO, A. (Orgs.). Uma escrita acadêmica outra: ensaios, experiências e invenções. Rio de Janeiro: Lamparina, 2016. p. 17-30.

LEVY, T. S. A experiência do fora - Blanchot, Foucault e Deleuze. Rio de Janeiro: Civilização Brasileira, 2011. 
LOPONTE, L. Do Nietzsche trágico ao Foucault ético: sobre estética da existência e uma ética para a docência. Educação e Realidade, v. 28, n. 2, p. 69-82. jul/dez. 2003. Disponível em: $<$ http://seer.ufrgs.br/educacaoerealidade/article/view/25641>. Acesso em: 10 fev. 2019.

LOPONTE, L. Arte para a docência: estética e criação na formação docente. Arquivos analíticos de políticas educacionais - Education Policy Analysis Archives, v. 21, n. 25, p. 1-18. mar/2013. Disponível em: <https://epaa.asu.edu/ojs/article/view/1145>. Acesso em: 10 jan. 2019.

OLIVEIRA, M. O. de; CHARRÉU, L. A. Contribuições da perspectiva metodológica "Investigação Baseada nas Artes" e da A/R/Tografia para as pesquisas em educação. Educação em Revista. Belo Horizonte, v.32, n.1, p. 365-382. jan./mar.2016. Disponível em: <http://www.scielo.br/scielo.php?pid=S0102-46982016000100365\&script=sci_abstract\&tlng=pt>. Acesso em: 15 jan. 2019.

SCHNOOR, F. Traças Pontos e linhas - Living Animals. 2012. Disponível em: <http:// fabiaschnoor.org/tracaspontos-e-linhas>. Acesso em: 12 dez. 2018.

SKLIAR, C. Desobedecer a linguagem: educar. Trad. G. Lessa. Belo Horizonte: Autêntica Editora, 2014.

Submetido: $24 / 03 / 2019$

Aprovado: 25/06/2019 